\title{
EFFECT OF LEISURE ACTIVITY ON QUALITY OF LIFE IN POST-STROKE PATIENTS
}

\author{
Wawan Ridwan Mutaqin, Ninik Nurhidayah
}

School of Health Polytechnics, Ministry of Health Surakarta

\begin{abstract}
Background: Stroke can cause impairment and disability so that the patient will have difficulty in doing daily activities, including self-care, productivity, and leisure time usage. This condition can decrease the quality of life of the poststroke patient. This study aimed to determine the effect of leisure activity on the quality of life of post-stroke patients.

Subjects and Method: This was a quasi experiment with pre and post design conducted in Ngemplak, Boyolali, Central Java. A sample of 25 post stroke patients was selected for this study by purposive sampling. The dependent variable was quality of life including physical health, psychological health, social relation, and environment. The quality of life was measured before and after intervention. The independent variable was leisure activity. The data were analyzed by Wilcoxon.

Results: 11 people (44\%) of the study subjects were elderly, 16 (65\%) were male, $20(80 \%)$ had married / had spouse, 8 (32\%) did not work, and $10(40 \%)$ suffered stroke over 24 months. Physical health after intervention (mean $=3.36, \mathrm{SD}=0.76$ ) was higher than before intervention (mean $=2.56, \mathrm{SD}=0.77$ ) with $\mathrm{p}=0.002$. The psychological condition after intervention (mean $=3.44 ; \mathrm{SD}=0.58$ ) was higher than before intervention $($ mean $=2.44, \mathrm{SD}=0.82)$ with $\mathrm{p}=0.001$. The social relationship after intervention (mean $=3.16 ; \mathrm{SD}=0.69$ ) was higher than before intervention $($ mean $=1.92 ; \mathrm{SD}=0.81)$ with $\mathrm{p}=0.001$. The environment after intervention (mean $=3.00 ; \mathrm{SD}=0.58$ ) was higher than before intervention (mean $=2.40 ; \mathrm{SD}=0.58$ ) with $\mathrm{p}<0.001$.

Conclusion: Leisure activity seems effective to improve the quality life of post stroke patients. A randomized control trial is recommended to provide stronger evidence on this effectiveness.
\end{abstract}

Keywords: leisure activity, quality of life, post stroke, patient

\section{Correspondence:}

Wawan Ridwan Mutaqin. School of Health Polytechnics, Ministry of Health Surakarta. Email: wridwanms3@gmail.com or d2rojaku_sayangku@yahoo.com 